Review

\title{
TWIST1 and BMII in Cancer Metastasis and Chemoresistance
}

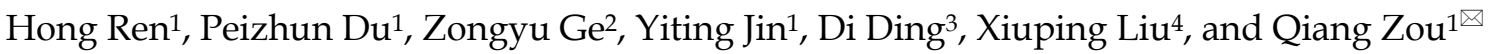 \\ 1. Department of General Surgery, Huashan Hospital, Fudan University, Shanghai, P.R. China \\ 2. Department of General Surgery, Huzhou Maternity and Child Health Care Hospital, Zhejiang Province, P.R. China \\ 3. Department of Pathology, Zhongshan Hospital, Fudan University, Shanghai, P.R. China \\ 4. Department of Pathology, Shanghai Medical College, Fudan University, Shanghai, P.R. China \\ $\triangle$ Corresponding author: Qiang Zou M.D., Ph.D. Department of General Surgery, Huashan Hospital, Fudan University, No 12, Wulumuqi Zhong Road, \\ Shanghai 200040, P. R. China; Tel.: +86 21 52889355; fax number: +86 21 52889355. E-mail: zouqiang1616@163.com
}

( ) Ivyspring International Publisher. Reproduction is permitted for personal, noncommercial use, provided that the article is in whole, unmodified, and properly cited. See http://ivyspring.com/terms for terms and conditions.

Received: 2015.10.02; Accepted: 2016.03.15; Published: 2016.05.25

\begin{abstract}
Purpose Increasing evidences revealed that cancer cells with the characteristics of epithelial-mesenchymal transition (EMT) or cancer stem cells (CSC) have high ability of progression, invasion, metastasis and chemoresistance. TWIST1 and BMII are crucial transcription factors required for EMT and CSC. Both TWISTI and BMII are up-regulated in various cancers and have a positive correlation with poor prognosis. Although recent results showed that the two molecules function in promoting cancer metastasis and chemoresistance respectively, the correlation of TWISTI and BMII is not well understood.
\end{abstract}

Methods In this review, we summarize recent advance in cancer research focus on TWIST1 and BMII in cancer metastasis and chemoresistance, and emphasize the possible link between EMT and CSC.

Results Further investigation of TWIST1 and BMII cooperately promote CSC proliferation due to EMT-associated effect will help to understand the mechanism of tumor cells metastasis and chemoresistance.

Conclusions TWISTI and BMII in cancer cells will be effective targets for treating chemoresistant metastatic lesions.

Key words: epithelial-mesenchymal transition, cancer metastasis, chemoresistance, cancer stem cells

\section{Introduction}

Metastasis is vital for tumor cells to migrate, and locate to distant organs. Epithelial-mesenchymal transition (EMT) is a crucial event for cell dissemination of epithelial tumors. Epithelial malignant cells connected with their neighbors and basal membrane. By pleiotropic cytokines and several signaling pathways, epithelial cells lose their polarity and cell-cell contacts step by step, finally become mesenchymal phenotype which facilitates migration [1-5]. Cancer stem cell (CSC) is the concept describes neoplastic tissues with self-renewing and stem-like cells characteristics, this highly tumorigenic cell type can play a pivotal role in cancer progression [6-8].

TWIST1 can promote EMT, and is widely expressed in human cancers. High expression of
TWIST1 points to high rate of metastasis, chemotherapeutic resistance and poor prognosis [9-11]. BMI1 is a member of polycomb group (PcG) family. The stemness feature of BMI1 makes it vigorous in the involvement of tumor onset and progression. Meanwhile, the expression of BMI1 is increased in numerous cancers, researchers also confirmed that knock down of BMI1 ameliorated tumor initiation and metastasis $[12,13]$.

\section{TWIST1 at the crossroad of EMT and CSC}

TWIST1 participates in CSC, and TWIST1-BCL2 dependent pathway can surstain CSC [14]. Epigenetically, MTDH can facilitate histone H3 acetylation on the TWIST1 promoter, and then 
increased TWIST1 drive the CSC expansion [15]. Ying Kong et al. [16] found that Hedgehog pathway maintains the tumor-initiating cell like properties by controlling the expression of TWIST1 and SNAIL.

To understand whether TWIST1 plays in EMT and CSC closely connected to each other, Benjamin Beck et.al [17] measured the mechanism of TWIST1 induced tumor stemness and EMT, and they found TWIST1 was required for skin tumor initiation and maintenance. But this tumor stemness is independent of EMT induced by TWIST1. Another study also shares the similar view with the evidence that uncoupled role of TWIST1 played in EMT and CSC [18]. The authors found that turn on TWSIT1 in breast cancer cells can induce EMT while stem cell like traits arised only after TWIST1 deactivation.

Contrarily, there are reports about TWIST1 plays in EMT induced CSC or CSC induced EMT. Yiwen Chang et al. [19] induced EMT by exposuring to extracellular ligands and that could not sufficiently promote cell to form spheres in culture over 4 serial passages. Since among TGF $\beta$, WNT3A, WNT5A, BMP4, only WNT3A can promote CSC phenotype. The authors then assessed CSC states using chromatin immunoprecipitation with high-throughput sequencing, and they found that a switch from $\beta$ -catenin/E-cadherin/SOX15 complex to $\beta$ -catenin/TWIST1/TCF4 complex after WNT3A stimulation. The latter complex binds to CSC-related gene promoters and facilitates to generate CSC properties. It turns out WNT pathway induced EMT can generate CSC ability. What's more, other researchers showed that the epithelial ovarian stem cancer cells can generate mesenchymal cells with migratory and tumorigenic capacity both in vivo and in vitro [20]. TWIST1 played in EMT and CSC and they did interact with each other, whether EMT induced CSC or CSC induced EMT.

\section{BMI1 at the crossroad of EMT and CSC}

Kinue Kurihara et al. [21] demonstrated that BMI1 was important factor in the promotion of EMT and invasion of tongue squamous cell carcinoma. BMI1 repressed the expression of mir-200 family, which were suppressors of EMT program [22]. Researchers found that mir-15a inhibited cell proliferation and EMT in pancreatic ductal adenocarcinoma via the downregulation of BMI1 [23]. What's more, BMI1 also played a role in the human telomerase reverse transcriptase-induced immortalization and EMT [24].

To address whether BMI1 can promote EMT and CSC at the same time, the authors tested the expression of BMI1, mammosphere ability, in vitro and in vivo metastatic ability after adding Estrogen receptor- $\alpha$ in to the breast cancer cells. And they found that Estrogen receptor- $\alpha$ inhibited EMT and stemness through the down regulation of BMI1 [25]. Besides, studies also showed that BMI1 regulate EMT and self-renewal ability by upregulating NANOG through the NF-kB pathway [26].

\section{TWIST1 and BMI1 in cancer metastasis}

TWIST1 has been identified as a putative oncogene and a key regulator of cancer metastasis [27]. TWIST1 is overexpressed in malignant tumors, such as breast cancer, esophageal squamous carcinoma, thyroid cancer, lung cancer, gastric carcinoma, colorectal cancer, hepatocellular carcinoma, pancreatic cancer, cervical carcinoma and it usually associated with poor prognosis [28-31]. $\mathrm{Ng}$ et al. [32] reported that TWIST1 induced N-cadherin to promote invasiveness in trophoblastic carcinoma. TWIST1 cooperates with KRAS to induce lung tumorigenesis by suppressing cellular senescence programs [28]. What's more, DiMeo et al. [33] observed that the down-regulation of the TWIST1 expression reduced lung metastasis in vivo.

MicroRNA can regulate carcinogenesis through affecting co-factors of EMT inducers. In invasive endometrial cancer cell lines, microRNA-106b can inhibit EMT through suppressing TWIST1 [34]. Seven microRNAs (miR-300, 382, 494, 495, 539, 543 and 544) can suppress EMT-related signaling network comprising TWIST1, BMI1, ZEB1/2 thus inhibit cancer progression [35].

BMI1 was upregulated in various cancers. High level of BMI1 in tumors of nasopharyngeal carcinoma patients was correlated with worse prognosis [36]. Furthermore, elevated BMI1 expression linked with poor prognosis in leukemia, as well as neuroblastoma, glioblastoma, hepatocellular carcinoma, and salivary gland cancer, lung, breast, gastric, ovarian, colorectal, prostate, and osteosarcoma cancer [37-40]. Researchers suggested that in neuroblastoma, BMI1 inhibits tumor suppressor gene including $p 14 A R F$, $p 16 I N K 4 a, K I F 1 B \beta$, TSLC1 [41]. BMI1 can activate the WNT pathway by repressing Dickkopf (DKK) family of WNT inhibitors to facilitate tumor progression [42]. Studies revealed that BMI1 and TWIST1 cooperated in cancer differentiation and metastasis $[43,44]$ (Table 1 ).

\section{TWIST1 and BMI1 in cancer chemoresistance}

TWIST1 can promote chemoresistance in human cancer cells. In breast cancer cells, TWIST1 expression has been shown to form resistance to paclitaxel through binding to $A K T$ promoter and enhance its transcriptional activity [45]. Zhu et al. [46] showed that in cervical carcinoma, TWIST1 RNAi partially 
reversed MDR phenotype, such as suppressing cell proliferation and sensitizing cells to cisplatin treatment. High TWIST1 expression were strong indicators of postoperative recurrence of esophageal squamous cell carcinoma patients [47]. TWIST1 was overexpressed in chronic myelogenous leukemia patients who predisposed to develop chemoresistance against standard treatment with tyrosine kinase inhibitor imatinib, and this imatinib resistance was connected with acquisition of EMT phenotype and high aggressive and invasive growth [48].

The ability of cancer cells to evade senescence and apoptosis under treatment of chemotherapy was helpful to tumor progression and metastasis. BMI1 can protect tumor cells from suffering apoptosis and it is responsible for the chemotherapy failure [13]. Experimental reduction of BMI1 protein levels using siRNA leaded to apoptosis and senescence in tumor cells and increases susceptibility to cytotoxic agents
$[37,40]$. BMI1 also has another way to protect cells from senescence and apoptosis though suppressing oxidative and DNA damage stresses [37]. Artemin can stimulate radio- and chemo-resistance through upregulating TWIST1 and BMI1 [14]. TWIST1 and BMI1 expressions in different cancer types with cancer chemoresistance are presented in Table 2.

\section{TWIST1 and BMI1 as prognostic indicator of cancer}

TWIST1 has been demonstrated as biomarker for prediction of poor prognosis in nasopharyngeal carcinoma, esophageal squamous cell carcinoma, oral cancer, tonsillar squamous cell carcinoma, breast cancer, lung cancer, colon cancer, prostate cancer, malignant pleural mesothelioma, osteosarcoma [19, 49-57].

Table 1. TWISTI and BMII expression in cancer metastasis

\begin{tabular}{|c|c|c|c|c|c|c|c|}
\hline \multirow[t]{2}{*}{ Cancer type } & \multirow[t]{2}{*}{ Model } & \multirow[t]{2}{*}{ Species } & \multirow[t]{2}{*}{ Xenografts } & \multicolumn{2}{|c|}{ Over-expressing effector } & \multirow[t]{2}{*}{ Metastasis } & \multirow[t]{2}{*}{ Reference } \\
\hline & & & & Twist1 & Bmi1 & & \\
\hline \multirow[t]{3}{*}{ Breast cancer } & 67NR,168FARN,4707,471 & Human & BALB/C mice & + & - & Lymph node,blood,lung & [94] \\
\hline & MCF10A, MDA-MB-231 & Human & SCID mice & - & + & Brain & [95] \\
\hline & Specimen of carcinoma & Human & - & - & + & Lymph node & [96] \\
\hline \multirow[t]{2}{*}{ Nasopharyngeal carcinoma } & CNE2,HONE-1, & & & & & & \\
\hline & specimen of carcinoma & Human & BALB/C mice & - & + & Lung & [97] \\
\hline \multirow[t]{2}{*}{ Oesophageal carcinoma } & NE3,EC1,EC18, ,KYSE520 & & & & & Lymph node,distant & [98] \\
\hline & specimen of carcinoma & Human & - & + & - & nodal & [99] \\
\hline Head and neck carcinoma & Specimen of carcinoma & Human & - & + & - & Lymph node & [100] \\
\hline Gastric cancer & Specimen of carcinoma & Human & - & - & + & Lymph node & [101] [102] \\
\hline \multirow[t]{3}{*}{ Hepatocellular carcinoma } & MHCC-97L,MHCC-97H & & & & & peritoneal, lymph node, & \\
\hline & Huh-7,PLC,H2P,H2M, & & & & & etc & \\
\hline & specimen of carcinoma & Human & - & + & - & & [103] \\
\hline Colon cancer & Specimen of carcinoma & Human & - & - & + & Lymph node & [104] \\
\hline Prostate cancer & $\begin{array}{l}\text { LnCap,PC-3,DU145, } \\
\text { specimen of carcinoma }\end{array}$ & Human & NSG mice & + & \pm & Lymph node, bone,lung & {$[105,106]$} \\
\hline Bladder cancer & $\begin{array}{l}\mathrm{RT} 4, \mathrm{~T} 24, \text { specimen of } \\
\text { carcinoma }\end{array}$ & Human & - & + & - & Lymph node & [107] \\
\hline \multirow[t]{2}{*}{ Melanoma } & Melanoma cells & & & & & & \\
\hline & specimen of carcinoma & Human & - & - & + & Brain,lymph node,etc & [108] \\
\hline
\end{tabular}

+ means positive; - means negative

Table 2. TWISTI and BMII expression in cancer chemoresistance

\begin{tabular}{|c|c|c|c|c|c|c|c|}
\hline \multirow[t]{2}{*}{ Cancer type } & \multirow[t]{2}{*}{ Model } & \multirow[t]{2}{*}{ Species } & \multicolumn{2}{|c|}{ Over-expressing effector } & \multirow[t]{2}{*}{ Chemotherapeutic drugs } & \multirow[t]{2}{*}{ Chemoresistance } & \multirow[t]{2}{*}{ Reference } \\
\hline & & & Twist1 & Bmi1 & & & \\
\hline Brain cancer & Astrocyte & Human & + & - & Paclitaxel & Yes & [96] \\
\hline Nasopharyngeal cancer & HNE1-T3 & Human & + & - & Taxol, Vincristine & Yes & [97] \\
\hline Tongue cancer & CAL27, SCC15, SCC25 & Human & + & + & Cisplatin & Yes & {$[98,99]$} \\
\hline \multirow[t]{2}{*}{ Breast cancer } & $\begin{array}{l}\text { MCF-7, MDA-MB-231, } \\
\text { MCF-7/TamR }\end{array}$ & Human & + & - & Paclitaxel, Tamoxifen & Yes & [109], [94] \\
\hline & MCF-7 & Human & - & + & Doxorubicin & & [100] \\
\hline Lung cancer & A549, NSCLC cells & Human & + & - & Cisplatin & Yes & {$[101,102]$} \\
\hline Hepatocellular carcer & SK-HEP-1, SMMC-7721 & Human & - & + & 5-Fluorouracil & Yes & [103] \\
\hline Chronic myeloid leukemia & CML cells & Human & + & - & Imatinib & Yes & [95] \\
\hline Osteosarcoma & SAOS-2 & Human & - & + & Cisplatin & Yes & {$[40]$} \\
\hline Pancreatic cancer & MiaPaCa2 & Human & - & + & Gemcitabine & Yes & [104] \\
\hline Ovarian cancer & A-2780, CP-70 & Human & - & + & Cisplatin & Yes & [105] \\
\hline Cervical cancer & Hela cells & Human & + & - & Cisplatin & Yes & {$[46]$} \\
\hline \multirow[t]{2}{*}{ Prostate cancer } & LNCaP, DU145, PC3 & Human & + & - & Taxol & Yes & [107] \\
\hline & LNCaP, SCC25 & Human & - & + & Docetaxol & & {$[108]$} \\
\hline
\end{tabular}

+ means positive; - means negative 


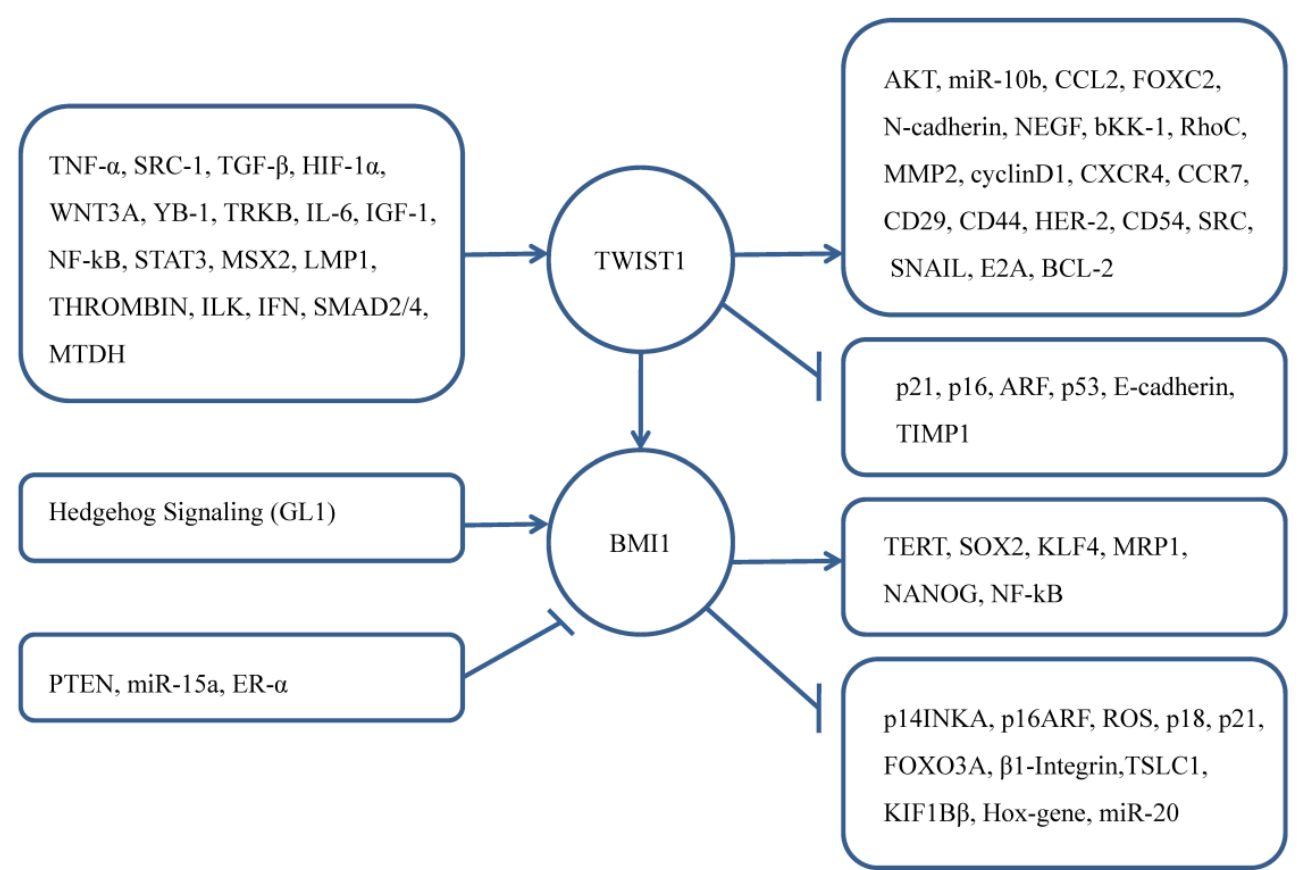

Figure 1. TWISTI and BMII contribute to a series of processes that affecting cancer proliferation, progression, invasion, metastasis and chemoresistance.

BMI1 also has been confirmed its progsnotic indicator role for brain tumors, head and neck cancer, tongue cancer, esophageal squamous cell carcinoma, lung adenocarcinoma, gastric cancer, renal cell carcinoma, colorectal cancer, ovarian cancer [58-66].

\section{Correlation of TWIST1 and BMI1}

As a regulator of EMT, TWIST1 participates in the cell proliferation and apoptosis processes. There are many upstream regulators of TWIST1 promote these vital process such as ARF-p53, NF-k $\beta$, AKT, WNT $[11,67-70]$. As a core effector of cell self-renewal activator, BMI1 was influenced by other genes that promote cell proliferation contributing to CSC [71-77]. Knockdown of BMI1 in TWIST1-overexpressing cells blocked both EMT and stem-like properties, while knockdown TWIST1 in BMI1-overexpressing cells reversed EMT and abolished stem-like properties. Researchers used quantitative chromatin immunoprecipitation assay to demonstrate that knockdown TWIST1 or BMI1 contributed to the decreased binding of the other molecule on both E-cadherin and p16INK4A [43]. That explained the interdependent relationship of TWIST1 and BMI1 in cancer cells.

What's more, NANOG controlled the expression of TWIST1 and BMI1 in the immunoedited tumor cells, and NANOG/TCL1A/AKT pathway can promote EMT- and CSC-mediated metastasis [78]. Kun Liu et al. [79] found that in the condition of hypoxia, TWIST1 and BMI1's cooperation can induce stemness by upregulating the expression of CD44 and OCT4. Increased vasculogenic mimicry can promote EMT. Therefore, TWIST1 and BMI1 must be interacted with each other, both are mutually essential for the EMT and tumor-initiating capability. More importantly, both high expression of TWIST1 and BMI1 can indicate poor prognosis of cancer patients $[43,80]$.

\section{Conclusions}

EMT plays a lot in the acquisition of invasive and migratory traits of many tumors[81, 82]. Studies showed that EMT can generate stem-like properties [83-85]. Some CSCs can turn to migratory CSCs under the effection of EMT and freely pass the vessles and lymphnodes, CSCs and cancer cells arising as the successors of EMT develop more resistant to conventional therapies [86-89]. Thus EMT facilitates the generation of tumor cells with self-renewal abilities needed for initiation of secondary tumors.

Meanwhile, cancer-stimulated mesenchymal stem cells secrets Prostaglandin E2 (PGE2), IL-6,IL-8, Gro- $\alpha \mathrm{r}$ which facilitates the CSC and EMT program in nearby cancer cells [90]. EMT and CSC is closely related. The EMT-CSC model carries more implications in the biology and treatment of cancer [85]. The research on EMT and CSC may find out more related genes affecting these vital processes. Therefore, the signaling pathways regulating EMT and CSC require more intensive investigation.

Both TWIST1 and BMI1 have been reported to be 
associated with cancer progression, metastasis and chemoresistance, while both TWIST1 and BMI1 can promote cancer initiation and recurrence. Is TWIST1 and BMI1 build a bridge that connect the EMT and CSC through which they can activate the growth of cells and leads to migration and metastasis still needs to be explored. Recently, experiments results showed that Doxycyline, Sirtuin SIRT6 and RNA-based TWIST1 inhibition via dendrimer complex can target TWIST1 in lung and breast cancer cells, finally reduce its metastatic potential [91-93]. $\mathrm{NaB}$ (histone deacetylase inhibitor) can therapeutically inhibit BMI1 in tongue cancer cells [61]. However, this is limited and more drugs that can target TWIST1 and BMI1 are needed for the effective treatment of metastatic cancers. Above all, it is of great clinical value to understand the molecular mechanism underlying the regulation of TWIST1 and BMI1 in the growth of EMT and CSC, and their cooperation to cancer metastasis and chemoresistance.

\section{Abbreviations}

EMT, epithelial-mesenchymal transition; CSC, cancer stem cells.

\section{Acknowledgement}

We thank Ying $\mathrm{Wu}$ for English editing and critical comments.

Support: This research was supported by Science and Technology Commission of Shanghai Municipality, China (No.15411952503 to Dr. Zou)

\section{Competing Interests}

The authors have declared that no competing interest exists.

\section{References}

1. Lee MY, Shen MR. Epithelial-mesenchymal transition in cervical carcinoma. Am J Transl Res. 2012; 4: 1-13

2. Kahlert UD, Nikkhah G, Maciaczyk J. Epithelial-to-mesenchymal(-like) transition as a relevant molecular event in malignant gliomas. Cancer Lett. 2013; 331: 131-8.

3. Casas E, Kim J, Bendesky A, Ohno-Machado L, Wolfe CI, Yang J. Snail2 is an essential mediator of Twist1-induced epithelial mesenchymal transition and metastasis. Cancer Res. 2011; 71: 245-54.

4. Barriere G, Riouallon A, Renaudie J, Tartary M, Rigaud M. Mesenchymal and stemness circulating tumor cells in early breast cancer diagnosis. BMC Cancer. 2012; $12: 114$.

5. Hollier BG, Evans K, Mani SA. The epithelial-to-mesenchymal transition and cancer stem cells: a coalition against cancer therapies. J Mammary Gland Biol Neoplasia. 2009; 14: 29-43.

6. Polytarchou C, Iliopoulos D, Struhl K. An integrated transcriptional regulatory circuit that reinforces the breast cancer stem cell state. Proc Natl Acad Sci U S A. 2012; 109: 14470-5.

7. Ferrari P, Nicolini A, Carpi A. Targeted therapies of metastatic breast cancer: relationships with cancer stem cells. Biomed Pharmacother. 2013; 67: 543-55.

8. Xu Y, Li Y, Pang Y, Ling M, Shen L, Yang X, et al. EMT and stem cell-like properties associated with HIF-2alpha are involved in arsenite-induced transformation of human bronchial epithelial cells. PLoS One. 2012; 7: e37765.

9. Brabletz T. EMT and MET in metastasis: where are the cancer stem cells? Cancer Cell. 2012; 22: 699-701.

10. Eide T, Ramberg H, Glackin C, Tindall D, Tasken KA. TWIST1, A novel androgen-regulated gene, is a target for NKX3-1 in prostate cancer cells. Cancer Cell Int. 2013; 13: 4.

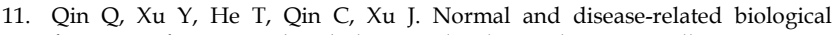
functions of Twist1 and underlying molecular mechanisms. Cell Res. 2012; 22: 90-106.

12. Ma J, Lanza DG, Guest I, Uk-Lim C, Glinskii A, Glinsky G, et al. Characterization of mammary cancer stem cells in the MMTV-PyMT mouse model. Tumour Biol. 2012; 33: 1983-96.

13. Siddique HR, Saleem M. Role of BMI1, a stem cell factor, in cancer recurrence and chemoresistance: preclinical and clinical evidences. Stem Cells. 2012; 30: 372-8.

14. Banerjee A, Qian P, Wu ZS, Ren X, Steiner M, Bougen NM, et al. Artemin stimulates radio- and chemo-resistance by promoting TWIST1-BCL-2-dependent cancer stem cell-like behavior in mammary carcinoma cells. The Journal of biological chemistry. 2012; 287: 42502-15.

15. Liang Y, Hu J, Li J, Liu Y, Yu J, Zhuang X, et al. Epigenetic Activation of TWIST1 by MTDH Promotes Cancer Stem-like Cell Traits in Breast Cancer. Cancer research. 2015; 75: 3672-80.

16. Kong Y, Peng Y, Liu Y, Xin H, Zhan X, Tan W. Twist1 and Snail link Hedgehog signaling to tumor-initiating cell-like properties and acquired chemoresistance independently of ABC transporters. Stem cells. 2015; 33: 1063-74.

17. Beck B, Lapouge G, Rorive S, Drogat B, Desaedelaere K, Delafaille S, et al. Different levels of Twist1 regulate skin tumor initiation, stemness, and progression. Cell stem cell. 2015; 16: 67-79.

18. Schmidt JM, Panzilius E, Bartsch HS, Irmler M, Beckers J, Kari V, et al. Stem-cell-like properties and epithelial plasticity arise as stable traits after transient Twist1 activation. Cell reports. 2015; 10: 131-9.

19. Chang YW, Su YJ, Hsiao M, Wei KC, Lin WH, Liang CL, et al. Diverse Targets of beta-Catenin during the Epithelial-Mesenchymal Transition Define Cancer Stem Cells and Predict Disease Relapse. Cancer research. 2015; 75: 3398-410.

20. Yin G, Alvero AB, Craveiro V, Holmberg JC, Fu HH, Montagna MK, et al. Constitutive proteasomal degradation of TWIST-1 in epithelial-ovarian cancer stem cells impacts differentiation and metastatic potential. Oncogene. 2013; 32: 39-49.

21. Kurihara K, Isobe T, Yamamoto G, Tanaka Y, Katakura A, Tachikawa T. Expression of BMI1 and ZEB1 in epithelial-mesenchymal transition of tongue squamous cell carcinoma. Oncology reports. 2015; 34: 771-8.

22. Martinez-Fernandez M, Duenas M, Feber A, Segovia C, Garcia-Escudero R, Rubio C, et al. A Polycomb-mir200 loop regulates clinical outcome in bladder cancer. Oncotarget. 2015; 6: 42258-75.

23. Guo S, Xu X, Tang Y, Zhang C, Li J, Ouyang Y, et al. miR-15a inhibits cell proliferation and epithelial to mesenchymal transition in pancreatic ductal adenocarcinoma by down-regulating Bmi-1 expression. Cancer letters. 2014; 344: $40-6$

24. Qiao B, Chen Z, Hu F, Tao Q, Lam AK. BMI-1 activation is crucial in hTERT-induced epithelial-mesenchymal transition of oral epithelial cells. Experimental and molecular pathology. 2013; 95: 57-61.

25. Wei XL, Dou XW, Bai JW, Luo XR, Qiu SQ, Xi DD, et al. ERalpha inhibits epithelial-mesenchymal transition by suppressing Bmi1 in breast cancer. Oncotarget. 2015; 6: 21704-17.

26. Paranjape AN, Balaji SA, Mandal T, Krushik EV, Nagaraj P, Mukherjee G, et al. Bmi1 regulates self-renewal and epithelial to mesenchymal transition in breast cancer cells through Nanog. BMC cancer. 2014; 14: 785.

27. Hui L, Zhang S, Dong X, Tian D, Cui Z, Qiu X. Prognostic significance of twist and N-cadherin expression in NSCLC. PLoS One. 2013; 8: e62171.

28. Tran PT, Shroff EH, Burns TF, Thiyagarajan S, Das ST, Zabuawala T, et al. Twist1 suppresses senescence programs and thereby accelerates and maintains mutant Kras-induced lung tumorigenesis. PLoS Genet. 2012; 8: e1002650.

29. Matsuo N, Shiraha H, Fujikawa T, Takaoka N, Ueda N, Tanaka S, et al. Twist expression promotes migration and invasion in hepatocellular carcinoma. BMC Cancer. 2009; 9: 240.

30. Ruppenthal RD, Nicolini C, Filho AF, Meurer R, Damin AP, Rohe A, et al. TWIST1 promoter methylation in primary colorectal carcinoma. Pathol Oncol Res. 2011; 17: 867-72.

31. Zhao N, Sun BC, Zhao XL, Liu ZY, Sun T, Qiu ZQ, et al. Coexpression of Bcl-2 with epithelial-mesenchymal transition regulators is a prognostic indicator in hepatocellular carcinoma. Med Oncol. 2012; 29: 2780-92

32. $\mathrm{Ng} \mathrm{YH}, \mathrm{Zhu} \mathrm{H}$, Leung PC. Twist modulates human trophoblastic cell invasion via regulation of N-cadherin. Endocrinology. 2012; 153: 925-36.

33. DiMeo TA, Anderson K, Phadke P, Fan C, Perou CM, Naber S, et al. A novel lung metastasis signature links Wnt signaling with cancer cell self-renewal and epithelial-mesenchymal transition in basal-like breast cancer. Cancer Res. 2009; 69: 5364-73.

34. Dong P, Kaneuchi M, Watari H, Sudo S, Sakuragi N. MicroRNA-106b modulates epithelial-mesenchymal transition by targeting TWIST1 in invasive endometrial cancer cell lines. Mol Carcinog. 2014; 53: 349-59.

35. Haga CL, Phinney DG. MicroRNAs in the imprinted DLK1-DIO3 region repress the epithelial-to-mesenchymal transition by targeting the TWIST1 protein signaling network. J Biol Chem. 2012; 287: 42695-707.

36. Song LB, Zeng MS, Liao WT, Zhang L, Mo HY, Liu WL, et al. Bmi-1 is a novel molecular marker of nasopharyngeal carcinoma progression and immortalizes primary human nasopharyngeal epithelial cells. Cancer Res. 2006; 66: 6225-32.

37. Cao L, Bombard J, Cintron K, Sheedy J, Weetall ML, Davis TW. BMI1 as a novel target for drug discovery in cancer. J Cell Biochem. 2011; 112: 2729-41. 
38. Marquardt JU, Factor VM, Thorgeirsson SS. Epigenetic regulation of cancer stem cells in liver cancer: current concepts and clinical implications. J Hepatol. 2010; 53: 568-77.

39. Parvathi MV, Murthy PB, Vennila M, Suresh BV. Regulation of BMI1 Polycomb gene expression in histological grades of invasive ductal breast carcinomas and its correlation with hormone receptor status. Tumour Biol. 2013; 34: 3807-15.

40. Wu Z, Min L, Chen D, Hao D, Duan Y, Qiu G, et al. Overexpression of BMI-1 promotes cell growth and resistance to cisplatin treatment in osteosarcoma. PLoS One. 2011; 6: e14648.

41. Kamijo T. Role of stemness-related molecules in neuroblastoma. Pediatr Res. 2012; 71: 511-5.

42. Cho JH, Dimri M, Dimri GP. A positive feedback loop regulates the expression of polycomb group protein BMI1 via WNT signaling pathway. J Biol Chem. 2013; 288: 3406-18.

43. Yang MH, Hsu DS, Wang HW, Wang HJ, Lan HY, Yang WH, et al. Bmi1 is essential in Twist1-induced epithelial-mesenchymal transition. Nature cell biology. 2010; 12: 982-92

44. Jagani Z, Wiederschain D, Loo A, He D, Mosher R, Fordjour P, et al. The Polycomb group protein Bmi-1 is essential for the growth of multiple myeloma cells. Cancer Res. 2010; 70: 5528-38.

45. Cheng GZ, Chan J, Wang Q, Zhang W, Sun CD, Wang LH. Twist transcriptionally up-regulates AKT2 in breast cancer cells leading to increased migration, invasion, and resistance to paclitaxel. Cancer Res. 2007; 67: 1979-87.

46. Zhu K, Chen L, Han X, Wang J, Wang J. Short hairpin RNA targeting Twist1 suppresses cell proliferation and improves chemosensitivity to cisplatin in HeLa human cervical cancer cells. Oncol Rep. 2012; 27: 1027-34.

47. Nakajima TE, Yoshida H, Okamoto N, Nagashima K, Taniguchi H, Yamada Y, et al. Nucleostemin and TWIST as predictive markers for recurrence after neoadjuvant chemotherapy for esophageal carcinoma. Cancer Sci. 2012; 103: 233-8.

48. Cosset E, Hamdan G, Jeanpierre S, Voeltzel T, Sagorny K, Hayette S, et al. Deregulation of TWIST-1 in the CD34+ compartment represents a novel prognostic factor in chronic myeloid leukemia. Blood. 2011; 117: 1673-6.

49. Zhuo X, Chang A, Huang C, Yang L, Xiang Z, Zhou Y. Expression of TWIST, an inducer of epithelial-mesenchymal transition, in nasopharyngeal carcinoma and its clinical significance. International journal of clinical and experimental pathology. 2014; 7: 8862-8.

50. Grzegrzolka J, Biala M, Wojtyra P, Kobierzycki C, Olbromski M, Gomulkiewicz A, et al. Expression of EMT Markers SLUG and TWIST in Breast Cancer. Anticancer research. 2015; 35: 3961-8.

51. Katz B, Reis ST, Viana NI, Morais DR, Moura CM, Dip N, et al. Comprehensive study of gene and microRNA expression related to epithelial-mesenchymal transition in prostate cancer. PloS one. 2014; 9: e113700.

52. Lee KW, Sung CO, Kim JH, Kang M, Yoo HY, Kim HH, et al. CD10 expression is enhanced by Twist1 and associated with poor prognosis in esophageal squamous cell carcinoma with facilitating tumorigenicity in vitro and in vivo. International journal of cancer Journal international du cancer. 2015; 136: 310-21.

53. Iwanami $\mathrm{T}$, Uramoto $\mathrm{H}$, Nakagawa $\mathrm{M}$, Shimokawa $\mathrm{H}$, Yamada $\mathrm{S}$, Kohno K, et al. Clinical significance of epithelial-mesenchymal transition-associated markers in malignant pleural mesothelioma. Oncology. 2014; 86: 109-16.

54. da Silva SD, Alaoui-Jamali MA, Soares FA, Carraro DM, Brentani HP, Hier M, et al. TWIST1 is a molecular marker for a poor prognosis in oral cancer and represents a potential therapeutic target. Cancer. 2014; 120: 352-62.

55. Kwon MJ, Kwon JH, Nam ES, Shin HS, Lee DJ, Kim JH, et al. TWIST1 promoter methylation is associated with prognosis in tonsillar squamous cell carcinoma. Human pathology. 2013; 44: 1722-9.

56. Padin-Iruegas ME, Herranz-Carnero M, Aguin-Losada S, Brozos-Vazquez E, Anido-Herranz U, Antunez-Lopez JR, et al. Prognostic value of changes in the expression of stem cell markers in the peripheral blood of patients with colon cancer. Oncology reports. 2013; 29: 2467-72.

57. Yin $\mathrm{K}$, Liao Q, He H, Zhong D. Prognostic value of Twist and E-cadherin in patients with osteosarcoma. Medical oncology. 2012; 29: 3449-55.

58. Yuan B, Zhao H, Xue X, Wang X, Han Y, Zhi Q, et al. Prognostic value and clinicopathological differences of Bmi1 in gastric cancer: a meta-analysis. Anti-cancer agents in medicinal chemistry. 2016;4:407-13.

59. Long Q, Liu L, Xia Y, Bai Q, Wang J, Xu J, et al. High peritumoral Bmi-1 expression is an independent prognosticator of poor prognosis in renal cell carcinoma. Tumour biology : the journal of the International Society for Oncodevelopmental Biology and Medicine. 2015; 36: 8007-14.

60. Espersen ML, Olsen J, Linnemann D, Hogdall E, Troelsen JT. Clinical implications of intestinal stem cell markers in colorectal cancer. Clinical colorectal cancer. 2015; 14: 63-71.

61. Li Z, Wang Y, Yuan C, Zhu Y, Qiu J, Zhang W, et al. Oncogenic roles of Bmi1 and its therapeutic inhibition by histone deacetylase inhibitor in tongue cancer. Laboratory investigation; a journal of technical methods and pathology. 2014; 94: 1431-45.

62. Zhang Y, Zhang YL, Chen HM, Pu HW, Ma WJ, Li XM, et al. Expression of Bmi-1 and PAI-1 in esophageal squamous cell carcinoma. World journal of gastroenterology. 2014; 20: 5533-9.

63. Allegra E, Trapasso S, Pisani D, Puzzo L. The role of BMI1 as a biomarker of cancer stem cells in head and neck cancer: a review. Oncology. 2014; 86: 199-205.
64. Abd El hafez A, El-Hadaad HA. Immunohistochemical expression and prognostic relevance of Bmi-1, a stem cell factor, in epithelial ovarian cancer. Annals of diagnostic pathology. 2014; 18: 58-62.

65. Zhang $X$, Sun J, Wang H, Lou Y, Zhang Y, Sha H, et al. IGF-1R and Bmi-1 expressions in lung adenocarcinoma and their clinicopathologic and prognostic significance. Tumour biology : the journal of the International Society for Oncodevelopmental Biology and Medicine. 2014; 35: 739-45.

66. Dahlrot RH, Hermansen SK, Hansen S, Kristensen BW. What is the clinical value of cancer stem cell markers in gliomas? International journal of clinical and experimental pathology. 2013; 6: 334-48.

67. Cheng GZ, Zhang W, Wang LH. Regulation of cancer cell survival, migration, and invasion by Twist: AKT2 comes to interplay. Cancer Res. 2008; 68: 957-60.

68. Li CW, Xia W, Huo L, Lim SO, Wu Y, Hsu JL, et al. Epithelial-mesenchymal transition induced by TNF-alpha requires NF-kappaB-mediated transcriptional upregulation of Twist1. Cancer Res. 2012; 72: 1290-300.

69. Li J, Zhou BP. Activation of beta-catenin and Akt pathways by Twist are critical for the maintenance of EMT associated cancer stem cell-like characters. BMC Cancer. 2011; 11: 49.

70. Yu W, Ruest LB, Svoboda KK. Regulation of epithelial-mesenchymal transition in palatal fusion. Exp Biol Med (Maywood). 2009; 234: 483-91.

71. Dimri GP, Martinez JL, Jacobs JJ, Keblusek P, Itahana K, Van Lohuizen M, et al. The Bmi-1 oncogene induces telomerase activity and immortalizes human mammary epithelial cells. Cancer Res. 2002; 62: 4736-45.

72. Dong P, Kaneuchi M, Watari H, Hamada J, Sudo S, Ju J, et al. MicroRNA-194 inhibits epithelial to mesenchymal transition of endometrial cancer cells by targeting oncogene BMI-1. Mol Cancer. 2011; 10: 99

73. Facchino S, Abdouh M, Bernier G. Brain cancer stem cells: current status on glioblastoma multiforme. Cancers (Basel). 2011; 3: 1777-97.

74. Fan C, He L, Kapoor A, Rybak AP, De Melo J, Cutz JC, et al. PTEN inhibits BMI1 function independently of its phosphatase activity. Mol Cancer. 2009; 8: 98

75. Li J, Gong LY, Song LB, Jiang LL, Liu LP, Wu J, et al. Oncoprotein Bmi-1 renders apoptotic resistance to glioma cells through activation of the IKK-nuclear factor-kappaB Pathway. Am J Pathol. 2010; 176: 699-709.

76. Liu S, Dontu G, Mantle ID, Patel S, Ahn NS, Jackson KW, et al. Hedgehog signaling and Bmi-1 regulate self-renewal of normal and malignant human mammary stem cells. Cancer Res. 2006; 66: 6063-71.

77. Wang E, Bhattacharyya S, Szabolcs A, Rodriguez-Aguayo C, Jennings NB, Lopez-Berestein G, et al. Enhancing chemotherapy response with Bmi-1 silencing in ovarian cancer. PLoS One. 2011; 6: e17918.

78. Lee HJ, Noh KH, Lee YH, Song KH, Oh SJ, Kim SY, et al. NANOG signaling promotes metastatic capability of immunoedited tumor cells. Clinical \& experimental metastasis. 2015; 32: 429-39.

79. Liu K, Sun B, Zhao X, Wang X, Li Y, Qiu Z, et al. Hypoxia promotes vasculogenic mimicry formation by the Twist1-Bmi1 connection in hepatocellular carcinoma. International journal of molecular medicine. 2015; 36: 783-91.

80. Ishikawa D, Shimada M, Utsunomiya $T$, Morine $\mathrm{Y}$, Imura $\mathrm{S}$, Ikemoto $\mathrm{T}$, et al. Effect of Twist and Bmi1 on intraductal papillary mucinous neoplasm of the pancreas. Journal of gastroenterology and hepatology. 2014; 29: 2032-7.

81. Thiery JP. Epithelial-mesenchymal transitions in development and pathologies. Curr Opin Cell Biol. 2003; 15: 740-6.

82. Hugo H, Ackland ML, Blick T, Lawrence MG, Clements JA, Williams ED, et al. Epithelial--mesenchymal and mesenchymal--epithelial transitions in carcinoma progression. J Cell Physiol. 2007; 213: 374-83.

83. Mani SA, Guo W, Liao MJ, Eaton EN, Ayyanan A, Zhou AY, et al. The epithelial-mesenchymal transition generates cells with properties of stem cells. Cell. 2008; 133: 704-15.

84. Lu H, Clauser KR, Tam WL, Frose J, Ye X, Eaton EN, et al. A breast cancer stem cell niche supported by juxtacrine signalling from monocytes and macrophages. Nat Cell Biol. 2014; 16: 1105-17.

85. Morel AP, Lievre M, Thomas C, Hinkal G, Ansieau S, Puisieux A. Generation of breast cancer stem cells through epithelial-mesenchymal transition. PLoS One. 2008; 3: e2888.

86. Barr S, Thomson S, Buck E, Russo S, Petti F, Sujka-Kwok I, et al. Bypassing cellular EGF receptor dependence through epithelial-to-mesenchymal-like transitions. Clin Exp Metastasis. 2008; 25: 685-93.

87. Li X, Lewis MT, Huang J, Gutierrez C, Osborne CK, Wu MF, et al. Intrinsic resistance of tumorigenic breast cancer cells to chemotherapy. J Natl Cancer Inst. 2008; 100: 672-9.

88. Thomson S, Buck E, Petti F, Griffin G, Brown E, Ramnarine N, et al. Epithelial to mesenchymal transition is a determinant of sensitivity of non-small-cell lung carcinoma cell lines and xenografts to epidermal growth factor receptor inhibition. Cancer Res. 2005; 65: 9455-62.

89. Woodward WA, Chen MS, Behbod F, Alfaro MP, Buchholz TA, Rosen JM. WNT/beta-catenin mediates radiation resistance of mouse mammary progenitor cells. Proc Natl Acad Sci U S A. 2007; 104: 618-23.

90. Li HJ, Reinhardt F, Herschman HR, Weinberg RA. Cancer-stimulated mesenchymal stem cells create a carcinoma stem cell niche via prostaglandin E2 signaling. Cancer Discov. 2012; 2: 840-55.

91. Qin Y, Zhang Q, Lee S, Zhong WL, Liu YR, Liu HJ, et al. Doxycycline reverses epithelial-to-mesenchymal transition and suppresses the proliferation and metastasis of lung cancer cells. Oncotarget. 2015; 6: 40667-79. 
92. Finlay J, Roberts CM, Lowe G, Loeza J, Rossi JJ, Glackin CA. RNA-based TWIST1 inhibition via dendrimer complex to reduce breast cancer cell metastasis. BioMed research international. 2015; 2015: 382745.

93. Han Z, Liu L, Liu Y, Li S. Sirtuin SIRT6 suppresses cell proliferation through inhibition of Twist1 expression in non-small cell lung cancer. International journal of clinical and experimental pathology. 2014; 7: 4774-81.

94. Yang J, Mani SA, Donaher JL, Ramaswamy S, Itzykson RA, Come C, et al. Twist, a master regulator of morphogenesis, plays an essential role in tumor metastasis. Cell. 2004; 117: 927-39.

95. Datta S, Hoenerhoff MJ, Bommi P, Sainger R, Guo WJ, Dimri M, et al. Bmi-1 cooperates with $\mathrm{H}$-Ras to transform human mammary epithelial cells via dysregulation of multiple growth-regulatory pathways. Cancer Res. 2007; 67: 10286-95.

96. Kim JH, Yoon SY, Jeong SH, Kim SY, Moon SK, Joo JH, et al. Overexpression of Bmi-1 oncoprotein correlates with axillary lymph node metastases in invasive ductal breast cancer. Breast. 2004; 13: 383-8.

97. Song LB, Li J, Liao WT, Feng Y, Yu CP, Hu LJ, et al. The polycomb group protein Bmi-1 represses the tumor suppressor PTEN and induces epithelial-mesenchymal transition in human nasopharyngeal epithelial cells. J Clin Invest. 2009; 119: 3626-36.

98. Yuen HF, Chan YP, Wong ML, Kwok WK, Chan KK, Lee PY, et al Upregulation of Twist in oesophageal squamous cell carcinoma is associated with neoplastic transformation and distant metastasis. J Clin Pathol. 2007; 60: $510-4$.

99. Sasaki K, Natsugoe S, Ishigami S, Matsumoto M, Okumura H, Setoyama T, et al. Significance of Twist expression and its association with E-cadherin in esophageal squamous cell carcinoma. J Exp Clin Cancer Res. 2009; 28: 158.

100. Ou DL, Chien HF, Chen CL, Lin TC, Lin LI. Role of Twist in head and neck carcinoma with lymph node metastasis. Anticancer Res. 2008; 28: 1355-9.

101. Liu JH, Song LB, Zhang X, Guo BH, Feng Y, Li XX, et al. Bmi-1 expression predicts prognosis for patients with gastric carcinoma. J Surg Oncol. 2008; 97: 267-72.

102. Zhang XW, Sheng YP, Li Q, Qin W, Lu YW, Cheng YF, et al. BMI1 and Mel-18 oppositely regulate carcinogenesis and progression of gastric cancer. Mol Cancer. 2010; 9: 40

103. Lee TK, Poon RT, Yuen AP, Ling MT, Kwok WK, Wang XH, et al. Twist overexpression correlates with hepatocellular carcinoma metastasis through induction of epithelial-mesenchymal transition. Clin Cancer Res. 2006; 12: 5369-76.

104. Li DW, Tang HM, Fan JW, Yan DW, Zhou CZ, Li SX, et al. Expression level of Bmi-1 oncoprotein is associated with progression and prognosis in colon cancer. J Cancer Res Clin Oncol. 2010; 136: 997-1006.

105. Kwok WK, Ling MT, Lee TW, Lau TC, Zhou C, Zhang X, et al. Up-regulation of TWIST in prostate cancer and its implication as a therapeutic target. Cancer Res. 2005; 65: 5153-62.

106. Talati PG, Gu L, Ellsworth EM, Girondo MA, Trerotola M, Hoang DT, et al. Jak2-Stat5a/b Signaling Induces Epithelial-to-Mesenchymal Transition and Stem-Like Cell Properties in Prostate Cancer. The American journal of pathology. 2015; 185: 2505-22.

107. Zhang Z, Xie D, Li X, Wong YC, Xin D, Guan XY, et al. Significance of TWIST expression and its association with E-cadherin in bladder cancer. Hum Pathol. 2007; 38: 598-606.

108. Mihic-Probst D, Kuster A, Kilgus S, Bode-Lesniewska B, Ingold-Heppner B, Leung $\mathrm{C}$, et al. Consistent expression of the stem cell renewal factor BMI-1 in primary and metastatic melanoma. Int J Cancer. 2007; 121: 1764-70.

109. Loh YN, Hedditch EL, Baker LA, Jary E, Ward RL, Ford CE. The Wnt signalling pathway is upregulated in an in vitro model of acquired tamoxifen resistant breast cancer. BMC Cancer. 2013; 13: 174. 